\title{
Presence of SARS-CoV-2 in urine is rare and not associated with acute kidney injury in critically ill COVID-19 patients
}

\author{
Robert Frithiof ${ }^{1 *} \mathbb{D}$, Anders Bergqvist ${ }^{2,3 \dagger}$, Josef D. Järhult ${ }^{4}$, Miklos Lipcsey ${ }^{1,5}$ and Michael Hultström,
}

Keywords: Acute kidney injury, Critical illness, COVID-19, SARS-CoV-2, Urine

\section{Dear Editor,}

Patients infected with SARS-CoV-2 requiring intensive care due to coronavirus disease 2019 (COVID-19) frequently develop acute kidney injury (AKI) [1], but the underlying mechanisms are poorly explored. SARS-CoV-2 has been found in both urine and the kidneys, where it has been suggested to cause proximal tubule damage [2-4]. Direct renal infection of SARS-CoV-2 causing AKI potentially leads to viral shedding in urine. However, to our knowledge, no study has been undertaken to investigate urinary levels of SARS-CoV-2 in patients with AKI.

In this report, SARS-CoV-2 RNA levels were prospectively investigated in urine of patients with upper or lower airway swab test PCR-verified COVID-19, admitted to a Swedish intensive care unit (ICU, $n=81$ ). The presented data is part of a study approved by the National Ethical Review Agency (2020-01623). Informed consent was obtained from the patient or next of kin. The Declaration of Helsinki and its subsequent revisions were followed. Nucleic acid was extracted from urine samples using NucliSENS $^{\oplus}$ eMAG $^{\odot}$ (bioMerieux), and the amount of viral RNA was quantitated by detection of SARS-CoV-2 $\mathrm{E}$ and $\mathrm{N}$-genes using real-

\footnotetext{
* Correspondence: robert.frithiof@surgsci.uu.se

${ }^{+}$Robert Frithiof and Anders Bergqvist contributed equally as first authors.

${ }^{1}$ Anesthesia and Intensive Care Medicine, Department of Surgical Sciences, Uppsala University, Uppsala, Sweden

Full list of author information is available at the end of the article
}

time RT-PCR according to previously described protocols [5, 6]. For quantitative assessment, the assay was calibrated against a synthetic RNA standard from ATCC and the detection limit was determined to 200 copies $/ \mathrm{ml}$.

SARS-CoV-2 was found in urine of only 6 patients (7\%). The median concentration was 1200 copies $/ \mathrm{ml}$ (range 300-2800). Urinary viral secretion was not associated with mortality or severity of disease as estimated by Simplified Acute Physiology Score 3 (SAPS3) on admission, length of stay in the ICU, the need for invasive ventilation, or renal replacement therapy (Table 1). Based on changes in plasma creatinine, $51(63 \%)$ patients developed AKI during their ICU stay. Only $5(10 \%)$ of those patients had detectable SARS-CoV-2 RNA levels in the urine. This indicates that urinary secretion of SARS-CoV-2 is uncommon in COVID-19-associated AKI. Furthermore, detection of SARS-CoV-2 RNA in urine was not significantly associated with renal dysfunction and was most frequent in the mildest stage of AKI (Table 1). Of interest is that positive samples in patients with AKI were collected significantly further from onset and peak AKI as compared to negative samples (Table 1).

Limitations of the present study include that urine was not sampled repeatedly in the same patient. In case of varying viral secretion, this may have led to an underestimation of the number of patients being positive prior 
Table 1 Patient characteristics and ICU treatment of 81 patients admitted to intensive care due to severe COVID-19 divided by findings of SARS-COV-2 in urine or not. Values are represented as median (IQR) or $n$ (\%). Data for "SAPS3" and "Days between onset of symptoms and sampling" were missing for one and 4 patients, respectively, in the group negative for SARS-COV-2 in urine. The $p$ value originates from the Mann-Whitney $U$ test for continuous parameters and the chi-square test for categorical parameters. Values are represented as median (IQR) or $n(\%) . p<0.05$ is considered significant. AKI acute kidney injury

\begin{tabular}{|c|c|c|c|}
\hline & $\begin{array}{l}\text { SARS-COV-2 urine negative } \\
(n=75)\end{array}$ & $\begin{array}{l}\text { SARS-COV-2 urine positive } \\
(n=6)\end{array}$ & $p$ \\
\hline Gender, female, $n(\%)$ & $17(23)$ & $2(33)$ & 0.57 \\
\hline Age, years & $61(53-70)$ & $58(39-69)$ & 0.59 \\
\hline Days between onset of symptoms and sample & $15(12-16), n=71$ & $14(12-16)$ & 0.68 \\
\hline Days between ICU admission and sample & $4(3-4)$ & $4(4-5)$ & 0.33 \\
\hline SAPS3 on admission & $53(47-57), n=74$ & $57(44-60)$ & 0.70 \\
\hline ICU-free days & $14(0-19)$ & $22(5-22)$ & 0.26 \\
\hline Ventilator-free days & $20(0-28)$ & $27(6-28)$ & 0.50 \\
\hline Renal replacement therapy-free days & $28(0-28)$ & $28(7-28)$ & 0.95 \\
\hline ICU mortality, n (\%) & $13(17)$ & $2(33)$ & 0.37 \\
\hline 30-day mortality, $n$ (\%) & $14(19)$ & $2(33)$ & 0.41 \\
\hline Acute kidney injury, $n$ (\%) & $46(61)$ & $5(83)$ & 0.28 \\
\hline Stage I & $23(31)$ & $4(67)$ & 0.07 \\
\hline Stage II & $9(12)$ & $0(0)$ & 0.36 \\
\hline Stage III & $14(19)$ & $1(17)$ & 0.90 \\
\hline Days between onset of AKI and sample & $2(-1-4), n=46$ & $6(5-8), n=5$ & 0.01 \\
\hline Days between peak $P$-creatinine and sample & $-2(-7-3), n=46$ & $5(4-5), n=5$ & 0.03 \\
\hline
\end{tabular}

to or during the complete ICU stay. Furthermore, AKI was determined based only on the change in plasma creatinine, not taking into account urine output. As AKI stages are defined by the maximum change of either plasma creatinine or urine output, we may have underestimated the incidence of AKI in this cohort. Finally, the low concentration of viral RNA in a limited number of patients prevents definitive conclusions regarding mechanisms of viral urinary secretion. A late onset of viral shedding in the urine may suggest a slowly developing glomerular filtration barrier dysfunction, but future studies are needed to investigate this in detail.

Here we show that urinary secretion of SARSCOV-2 is scarce in critically ill COVID-19 patients. In this cohort, SARS-CoV-2 RNA was not more frequently detected in urine of patients that died or developed acute kidney injury. This suggests that determining viral presence in urine will not aid in predicting or grading renal dysfunction or severity of disease in COVID-19. Our findings do not support direct renal SARS-COV-2 infection as an important mechanism of COVID-19-induced AKI, since renal infection likely would result in viral shedding in urine and thus a higher frequency of PCR positivity in urine of patients with AKI.

\section{Acknowledgements \\ The authors thank research nurses Joanna Wessbergh and Elin Söderman and the biobank assistants Erik Danielsson and Philip Karlsson for their expertise in compiling the study.}

\section{Authors' contributions}

All authors participated in the conception and design of the study. $A B$ performed the urinary analysis. All authors had access to the data and participated in the data collection and interpretation. RF drafted the manuscript, and all authors contributed to manuscript revision and gave approval of the final version.

\section{Funding}

The study was funded by the SciLifeLab/KAW national COVID-19 research program project grant to MH (KAW 2020.0182) and the Swedish Research Council to RF (2014-02569 and 2014-07606). Open Access funding provided by Uppsala University.

Availability of data and materials

Data in the current study is available from the corresponding author on a reasonable request.

\section{Ethics approval and consent to participate}

The study was approved by the Swedish National Ethical Review Agency (EPM; no. 2020-01623). Informed consent was obtained from the patient or next of kin.

\section{Consent for publication}

Not applicable.

Competing interests

The authors declare that they have no competing interests. 


\section{Author details}

'Anesthesia and Intensive Care Medicine, Department of Surgical Sciences, Uppsala University, Uppsala, Sweden. ${ }^{2}$ Clinical Microbiology and Infection Medicine, Department of Medical Sciences, Uppsala University, Uppsala, Sweden. ${ }^{3}$ Clinical Microbiology and Hospital Infection Control, Uppsala University Hospital, Uppsala, Sweden. ${ }^{4}$ Zoonosis Science Center, Department of Medical Sciences, Uppsala University, Uppsala, Sweden. ${ }^{5}$ Hedenstierna Laboratory, CIRRUS, Anesthesiology and Intensive Care, Department of Surgical Sciences, Uppsala University, Uppsala, Sweden. ${ }^{6}$ Integrative Physiology, Department of Medical Cell Biology, Uppsala University, Uppsala, Sweden.

Received: 3 September 2020 Accepted: 21 September 2020 Published online: 29 September 2020

\section{References}

1. Chen YT, Shao SC, Lai EC, Hung MJ, Chen YC. Mortality rate of acute kidney injury in SARS, MERS, and COVID-19 infection: a systematic review and meta-analysis. Crit Care. 2020;24(1):439.

2. Remmelink M, De Mendonca R, D'Haene N, De Clerca S, Veroca C, Lebrun L, Lavis P, Racu ML, Trepant AL, Maris C, et al. Unspecific post-mortem findings despite multiorgan viral spread in COVID-19 patients. Crit Care. 2020;24(1):495.

3. Bronimann S, Rebhan K, Lemberger U, Misrai V, Shariat SF, Pradere B. Secretion of severe acute respiratory syndrome coronavirus 2 in urine. Curr Opin Urol. 2020;30(5):735-9.

4. Werion A, Belkhir L, Perrot M, Schmit G, Aydin S, Chen Z, Penaloza A, De Greef J, Yildiz H, Pothen L, et al. SARS-CoV-2 causes a specific dysfunction of the kidney proximal tubule. Kidney Int. 2020. https://doi.org/10.1016/j.kint. 2020.07.019.

5. Corman VM, Landt O, Kaiser M, Molenkamp R, Meijer A, Chu DK, Bleicker T, Brunink S, Schneider J, Schmidt ML et al: Detection of 2019 novel coronavirus (2019-nCoV) by real-time RT-PCR. Euro Surveill. 2020;25(3):1-8.

6. CDC 2019-Novel Coronavirus (2019-nCoV) Real-Time RT-PCR Diagnostic Panel. Centers for Disease Control and Prevention Division of Viral Diseases. 1600 Clifton Rd NE. Atlanta; 2020. https://www.fda.gov/media/134922/ download.

\section{Publisher's Note}

Springer Nature remains neutral with regard to jurisdictional claims in published maps and institutional affiliations.

Ready to submit your research? Choose BMC and benefit from:

- fast, convenient online submission

- thorough peer review by experienced researchers in your field

- rapid publication on acceptance

- support for research data, including large and complex data types

- gold Open Access which fosters wider collaboration and increased citations

- maximum visibility for your research: over $100 \mathrm{M}$ website views per year

At $\mathrm{BMC}$, research is always in progress.

Learn more biomedcentral.com/submissions 